\title{
Bilgi Edinme Hakkı Kanunu ve Kurumsal Bilgi Yönetimi İlişkisi
}

\author{
Freedom of Information Law and Relation with \\ Organizational Knowledge Management
}

\section{Hakan Anameriç*}

\begin{abstract}
Öz
Türkiye'de sürdürülmekte olan e-Devlet çalışmaları ve Avrupa Birliği uyum projeleri kapsamında birçok kanun ve yeni düzenleme yapılmaktadır. Bu düzenlemelerden biri de, hem kamu kurum ve kuruluşların ellerindeki bilgiyi daha verimli ve etkin bir biçimde yönetmelerini sağlayacak, hem de vatandaşların kamu hizmetleri konusunda bilgi edinme hakkını yerine getirecek olan "Bilgi Edinme Hakkı Kanunu"dur. Sözü edilen kanun, şu anda 50 kadar ülkede yürürlüktedir ve demokratik ve şeffaf yönetimin gereği olan eşitlik, tarafsızlık ve açıklık ilkelerine uygun olarak kişilerin bilgi edinme hakkını kullanmalarına ilişkin esas ve usulleri düzenlemek için hazırlanmıştır. Böylece kurum ve kuruluşların üretmiş oldukları kurumsal bilgi kontrol altına alınacak, güvenlik, gizlilik ve paylaşılabilirlik sınırları belirlenecektir.
\end{abstract}

Anahtar sözcükler: Bilgi Edinme Hakkı Kanunu-Türkiye, Bilgi edinme özgürlüğü, Bilgi yönetimi, Belge yönetimi, Kurumsal bilgi yönetimiTürkiye.

\begin{abstract}
In the realm of projects aiming at the Turkish orientation and adjustment to European Union jurisdiction, and the formation of Turkish e-government nowadays, a considerable amount of legal enactments take place in Turkey. One of those is the "law pertaining the right to be
\end{abstract}

*Arş. Gör.; Ankara Üniversitesi Dil ve Tarih-Coğrafya Fakültesi Bilgi ve Belge Yönetimi Bölümü 06100 Sıhhıye-Ankara (anameric@humanity.ankara.edu.tr). 
informed", which would secure the citizens' right to gather information about public services, and would at the same time increase the management of knowledge effectiveness and productivity of government agencies. The mentioned legal regulations being also promulgated in about 50 countries, signify the rights and procedures of personal access to information according to principles of equality, independence and clarity, that would be necessitated by democratic and transparent administration. The law would thus enable the control of information being produced by government agencies, and its limitations concerning the confidentiality, trustworthiness and distributive propagation.

Keywords: Freedom of Information Act-Turkey, Freedom of information, Knowledge management, Records management, Organizational knowledge management-Turkey.

\section{Giriş}

Ülkemizde sürdürülen e-devlet çalışmaları, hazırlanan yasa tasarıları, taslak planlar, ara raporlar ve yürürlüğe giren kanunlar ile yeni bir ivme kazanmıştır. e-Devlet çalışmaları ile kazandırılan bu ivme, Türkiye'nin bilgi toplumuna geçiş çalışmalarının hızlandırılması, bilgi toplumu strateji ve politikalarının belirlenerek bu alandaki faaliyetlerin bir bütünlük içerisinde yürütülmesini amaçlamaktadır.

Son on yıldır ülkemizde Avrupa Birliği üyelik çalışmaları ile birlikte yürütülmekte olan e-devlet çalışmaları birçok alanda ilerleme kaydetmiştir. Devleti meydana getiren kurumların hemen hemen tümü bu çalışmalar içerisinde kendilerine düşen görevleri yerine getirmek için çaba harcamaktadır. e-Devlet çalışmaları, kamu kurum ve kuruluşlarını kapsamakta ve bu kurumların vatandaşlara daha hızlı, doğru, denetimli ve yeterli hizmet vermeleri amacında birleşmektedir. Bu çalışmaların diğer amaçları ise; kamu kurum ve kuruIuşlarındaki bürokrasiyi azaltmak, zaman kaybını önlemek, kurumların faaliyetlerini yürütürken ortaya çıkan belge ve bilgileri belirlenecek standartlara göre üretmek, sınıflandırmak, depolamak, saklamak ve kullanıma açmaktır. Aslında belge yönetimi olmadan sözü edilen hizmetleri ve bu hizmetlerin veriliş tarzı (hız, yeterlilik, güvenilirlik vb.) sağlıkı bir nitelik kazanmayacaktır. 
Tabii ki bu yapılanmada öncelikli olan nokta, işlemlerin ve hizmetlerin vatandaş ve kurumlar arasında elektronik olarak sürdürülmesini sağlamaktır. O halde e-devlet çalışmaları kamu kurum ve kuruluşlarının yönetim ve denetimlerinin kolaylaştırılması açısından ele alındığında kurumsal, bilgi ve belge üretimlerini ve yönetimini de kapsadığı söylenebilir.

Kamu kurum ve kuruluşlarının kendi bünyelerinde üretmiş oldukları ve doğal faaliyetleri sonucunda ortaya çıkan bilgiye kurumsal bilgi adı verilmektedir. Kurumsal bilgi, kurum ve kuruluşların işlemleri süresince gerçekleştirmiş oldukları, kurumların etkinliğinin artırılması, denetiminin daha sağlıklı bir biçimde yapılması, yönetiminin verimli hale getirilmesi, hizmetlerinin geliştirilmesi gibi süreçlerde kullandıkları her türlü belge, düşünce, fikir ve olgulardır (Özdemirci, 2001, s. 180). Kurumsal bilgi, kurum ve kuruluşların iş etkinlikleri içerisinde ortaya çıkmaktadır.

Kurumsal bilgi yönetiminin yanı sıra belge ve bilgi yönetimi kavramları da, günümüzde her türlü kurum için büyük önem taşıyan kavramlar olarak karşımıza çıkmaktadır. Dünyada ve ülkemizde bu konularla ilgili yayınlarda önemli bir artış görülmekte, bunun sonucu olarak da belge ve bilgi yönetimi konularına olan ilgi artmaktadır. Çünkü kurumların kendi belge ve bilgilerini yönetmeleri, daha verimli çalışmaları, üretim yapmaları, rekabeti sürdürmeleri ve kendilerini daha etkin denetlemeleri demektir. Bu nedenle kurum ve kuruluşlar sözü edilen işlemleri yerine getirebilmek amacıyla kendi bünyelerinde belge ve bilgi üretimini standart bir şekle sokmak ve üretilen belge ve bilgileri kullanıma açarak katma değerli yeni bilgi üretmek zorunda kalmışlardır.

"Bilgi Edinme Hakkı Kanunu", kamu kurum ve kuruluşlarının hem belge yönetimini kolaylaştıracak hem de vatandaşların kamu kurum ve kuruluşlarının faaliyetleri hakkında bilgi alma haklarını uygulamaya geçirecek bir düzenleme olarak değerlendirilmesi gerekmektedir.

\section{Bilgi Edinme Hakkı Kanunu}

Bilgi paylaşıldıkça değer kazanan bir nesnedir. Bu nedenle bilgi üretmek kadar bilginin paylaşılması da önemlidir. Ancak günümüzde küreselleşme şemsiyesi altında, içinde bulunduğumuz dünya düzeninde bilginin kazanmış olduğu önem, bu paylaşımın yasalarla düzenlenmesini gündeme getirmiş ve çeşitli ülkeler bu yasal düzenlemeyi konuyla ilgili yasalarını hazırlayıp uygulamaya geçirmişlerdir. Ülkemizde özellikle son on yıldır Avrupa Birliği'ne üye- 
lik ve e-Türkiye çalışmaları kapsamında birçok eylem planı hazırlanmış ve bu planlar çerçevesinde siyasi, sosyal, ekonomik, kültürel ve eğitim ile ilgili yasal düzenlemeler oluşturulmuştur. Bu çalışmalardan en yenisi son yıllarda üzerinde çalışılan, e-Türkiye Girişimi Eylem Planlarında ve son olarak 04.12.2003 tarih ve 25306 sayılı Resmî Gazete'de yayınlanan "Başbakanlık Genelgesi"nde "e-Dönüşüm Türkiye Projesi Kısa Dönem Eylem Planı 20032004"te yer alan "Bilgi Edinme Hakkı Kanunu" dur (Genelge, 2003, s. 13). Bu kanun önceki tekliflerde "Idari Usul ve Bilgi Edinme Hakkı Kanunu" olarak ele alınmış, daha sonra "Idari Usul Kanunu" ile "Bilgi Edinme Hakkı Kanunu"nu iki ayrı tasarı halinde hazırlanmış, ancak işlevsel açıdan bütünlük göstermeleri nedeniyle ön taslakla birleştirilmiştir. Kanun birleştirilmiş olmasına rağmen "Idarî Usul" ile ilgili kısmı "Kamu Yönetimi Temel Kanunu Tasarısı" görüşmeleri nedeniyle tasarıdan ayrılmış ve yalnızca "Bilgi Edinme Hakkı Kanunu" adıyla hazırlanmıştır (Idari, 1999, s. 1). Ancak bu kanunun tam ve sağlıklı olarak işlemesi için tasarıda sunulan ve kamu kurum ve kuruluşlarının idari usul işlemlerini düzenleyen bölümü ile birlikte ele alınarak uygulanması daha doğru olacaktır.

Bilgi edinme özgürlüğünün kanunlarla düzenlenerek uygulandığı ülke sayısı çok fazla değildir. Bilgi edinme özgürlüğü ile ilgili kanunları ilk olarak yürürlüğe koyan ülke 1766 yılında İsveç’tir. İsveç bu kanunu 1949 yılında yenilemiştir. Bu ülkeyi sırasıyla Finlandiya (1919/1951/1999), ABD (1966), Norveç (1970), Avustralya (1982), Yeni Zelanda (1982), Danimarka (1985) ve Kanada (1985) izlemiştir (Freedom, 2004; İimsoy, 1996, ss. 47-54). 2000 yılı itibariyle, dünya üzerinde 17 ülke bilgi edinme hakkı ile ilgili yasaları yürürlüğe koymuş, en az 23 ülkede ise hükümetler ellerindeki bilgiyi yurttaşlarına açmayı öngören çeşitli yasaları benimsemiş bulunmaktadır (Tortop, 2003). 2004 yılı itibariyle dünya üzerinde bilgi edinme hakkı kanunu yürürlükte olan ülkeler şu şekilde sıralanabilir; İsveç, Finlandiya, Norveç, Danimarka, Izlanda, ABD, İlanda, Ingiltere (Birleşik Krallık), Avusturya, İsviçre, Fransa, Yunanistan, Hollanda, Belçika, İtalya, Ispanya, Portekiz, Macaristan, Ukrayna, Özbekistan, Letonya, Gürcistan, Çek Cumhuriyeti, Bulgaristan, BosnaHersek, Estonya, Litvanya, Slovakya, Moldova, Polonya, Romanya, Slovenya, Türkiye, Hırvatistan, Japonya, Avustralya, Yeni Zelanda, İsrail, Güney Kore, Güney Afrika Cumhuriyeti, Hindistan, Tayland, Pakistan, Peru, Kolombiya, Panama, Meksika, Trinidad-Tobago, Burma ve Zimbabwe (Freedom, 2004) (Bkz. Harita) 


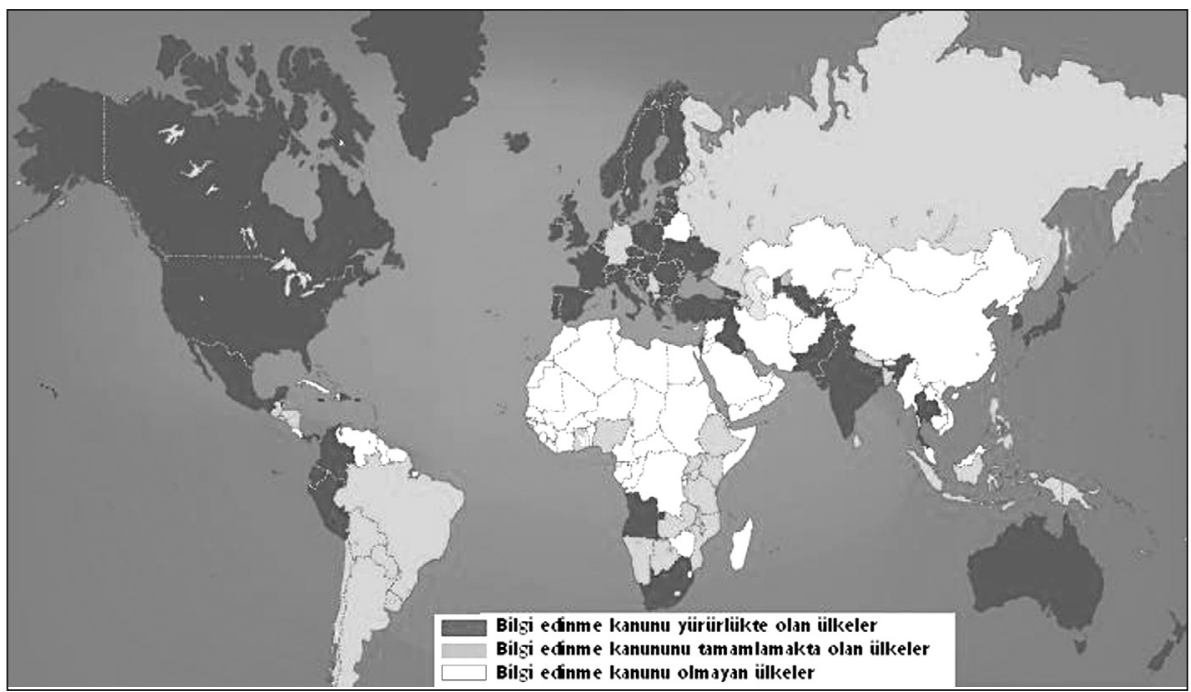

Harita : Dünyada Bilgi Edinme Kanunu Dağılımı (Kaynak: Access to information laws around the world. http://www.privacyinternational.org /issues/ foia/foialaws.jpg).

Bilgi Edinme Hakkı Kanunu, demokratik ve şeffaf yönetimin gereği olan eşitlik, tarafsızlık ve açıklık ilkelerine uygun olarak kişilerin bilgi edinme hakkını kullanmalarına ilişkin esas ve usulleri düzenlemek amacıyla hazırlanmıştır. (Bilgi, 2003a, s. 1). Anayasamızda da vatandaşların bilgi edinmesi, bilgi edinme hakkı ve bilgi edinme hakkının sınırlandırılması ile ilgili maddeler yer almaktadır. Anayasanın 26. maddesinin ikinci fıkrasında düşünceyi açıklama ve yayma hürriyetinin hangi ölçülere göre sınırlandırılabileceği gösterilirken, sözü edilen hürriyetlerin kullanılması "devlet sırrı olarak usulünce belirtilmiş bilgilerin açıklanmaması amaçlarıyla sınırlanabilir" denilmiş, Anayasa'nın 28. maddesinin dördüncü fıkrasında ise, devlete ait gizli bilgilere ilişkin bulunan her türlü haber veya yazıyı, yazanların veya bastıranların veya aynı amaçla, basanların, başkasına verenlerin bu suçlara ait kanun hükümleri uyarınca sorumlu olacakları açıklanmışı ır (T.C. Anayasa, 1999, ss. 43-44).

"Bilgi Edinme Hakkı Kanunu", kamu kurum ve kuruluşları ile kamu kurumu niteliğindeki meslek kuruluşlarının faaliyetlerinde uygulanmak ve bilgi edinme hakkının bir gereği olarak, bu Kanun ve diğer kanunlardaki sınırlama- 
lar saklı kalmak üzere (01.11.1984 tarihli ve 3017 sayılı Dilekçe Hakkının Kullanılmasına Dair Kanun) hiçbir kamu kurum ve kuruluşu ile kamu kurumu niteliğindeki meslek kuruluşunun faaliyetlerinin kapsam dışı kalmaması amacıyla hazırlanmıştır.

Kanun kapsamında belge, bilgi ve bunlara erişimle ilgili tanımlar yapılmış ve sözü edilen kavramların içerikleri belirlenmiştir. Kanun kapsamında bilgi kurum ve kuruluşların sahip oldukları kayıtlarda yer alan "Bilgi Edinme Hakkı Kanunu" kapsamındaki her türlü veri; belge kurum ve kuruluşların sahip oldukları "Bilgi Edinme Hakkı Kanunu" kapsamındaki yazılı, basılı ve çoğaltılmış dosya, evrak, kitap, dergi, broşür, etüt, mektup, program, talimat, kroki, plan, film, fotoğraf, teyp ve video kaseti, harita, elektronik ortamda kaydedilen her türlü bilgi, haber ve veri taşıyıcıları; bilgi / belgeye erişim ise istenilen bilgi ve belgenin niteliğine göre, kurum ve kuruluşlarca, başvuru sahibine (bilgi talebinde bulunan gerçek ve tüzel kişiler) söz konusu bilgi veya belgenin bir kopyasının verilmesi şeklinde tanımlanmıştır (Bilgi, 2003a, ss. 3-4). Kanun kapsamında tanımlanan bilgi ve belge kavramları kurumsal bilgi yönetimi ve bilgi üretim süreci ile de yakından ilgilidir. Çünkü burada kurum ve kuruluşların bünyelerinde bulunan ve ürettikleri bilgi ve belgeden söz edilmektedir.

"Bilgi Edinme Hakkı Kanunu"na göre herkes bilgi edinme hakkına sahiptir. Bu hak doğrultusunda kurum ve kuruluşlar kanunda yer alan istisnalar ve diğer sınırlamalar çerçevesinde her türlü bilgi ve belgeyi bilgi edinme talebinde bulunan gerçek ve tüzel kişilerin yararlanmasına sunmak ve bilgi edinme başvurularını etkin, hızlı ve doğru bir biçimde sonuçlandırmak üzere gerekli idarî ve teknik önlemleri almakla yükümlüdürler. Bilgi edinme başvurularının karşılanması için kurum ve kuruluşların üretmiş oldukları tüm bilgi ve belgeyi etkin bir biçimde kontrol etmeleri ve kurumun bilgi kaynaklarını düzenlemesi gerekmektedir. Buna göre, kanun kapsamında yer alan bilgi edinme başvurularının karşılanmasındaki temel gerekliliğin, ilgili kurumda bir belge yönetimi uygulaması olduğu sonucu çıkarılabilir.

Kanun'da bilgi edinme başvurusuna konu olacak bilgi veya belge, kurum ve kuruluşların ellerinde bulunan veya gösterdikleri faaliyet ve işlemler gereği ellerinde bulunması gereken bilgi ve belgeleri kapsamaktadır. Kurum ve kuruluşlar, ayrı veya özel bir çalışma, araştırma, inceleme ya da analiz sonu- 
cunda oluşturulabilecek türden bilgi veya belge için yapılacak başvurulara olumsuz cevap verebilirler. İstenilen bilgi veya belge, bilgi edinme başvurusu yapılan kurum ve kuruluşlardan başka bir yerde bulunuyorsa, başvuru dilekçesi bu kurum ve kuruluşlara gönderilir ve durum başvuru sahibine yazılı olarak bildirilir. Bilgi edinme başvurularının, ancak başvurulan kurum ve kuruluşların ellerinde bulunan veya görevleri gereği bulunması gereken bilgi veya belgelere ilişkin olması gerektiği şüphesizdir. Yine de başvuru sahipleri tarafından bu kuralın aksine bir başvuru yapılmışsa ve istenen bilgi veya belge başvurulan kurum ve kuruluştan başka bir yerde bulunuyorsa, başvurulan kurum ve kuruluşa, başvuru dilekçesini istenen bilgi veya belgenin bulunduğu kurum ve kuruluşa gönderme ve durumu ilgiliye yazılı olarak bildirme yükümlülüğü getirilmiştir. İstenilen bilgi ve belgelerin kurum ve kuruluşların bünyelerinde olup olmadığının belirlenmesi, hangi yayınların yayınlandığını ve hangi belgelerin kurum bünyesinde bulunmadığının belirlenmesi gerekmektedir. Bunun yapılabilmesi için öncelikli olarak bibliyografik denetim ve belge yönetimi işlemlerinin yerine getirilmesi daha sonra kurumsal bilgi yönetimi sürecinin işlemesi gerekmektedir.

"Bilgi Edinme Hakkı Kanunu"nda yayımlanmış ve kamuya açıklanmış bilgi ve belgeler bilgi edinme başvuruları dışında tutulmuştur. Kurum ve kuruluşlar tarafından yayımlanmış veya yayın, broşür, ilan vb. yollarla kamuya duyurulmuş bilgi veya belgeler, bu kanun kapsamı içerisinde yer almamaktadır. Ancak kanun hükümleri gereğince yayımlanmış veya kamuya açıklanmış bilgi veya belgelerin ne şekilde, ne zaman ve nerede yayımlandığı veya açıklandığı başvuru sahibine bildirilecektir. Kanunun ilgili maddesi (8. madde), önce "İdarî Usul ve Bilgi Edinme Hakkı Kanunu Ön Taslağı”nın "Bilgi Edinme Hakkı Kanunu" başlıklı bölümünün 22. maddesinde "Kamu kurum ve kuruluşlarınca yayımlanmış veya yayın, broşür, ilan ve benzeri yollarla vatandaşa açıklanmış ya da kütüphane ve benzeri halka açık yerlerde kolayca erişilebilecek bilgi ve dokümanlar da bu kanun kapsamı dışındadır" şeklinde ifade edilmiştir (Idarî, 1999, s. 15). Kanunun asıl ve tasarı metninden de anlaşılacağı üzere kamu kurum ve kuruluşları kendi bünyelerinde hazırlamış, yayımlamış ve kamuya açmış oldukları bilgi ve belgeleri kontrol etmek, denetlemek ve başvuru sahiplerini gerekli yerlere yönlendirmek ile yükümlüdürler. Bu da daha önce belirtildiği gibi bibliyografik denetimi ve belge yönetimini zorunlu kılmaktadır. 
Kanun'da bilgi ve belgeye erişim usullerinin yanı sıra bilgi ve belgeye erişim süreleri de belirlenmiştir. Bilgi edinme hakkının tam olarak kullanılabilmesinin sağlanması amacıyla bilgi veya belgeye erişimin her türlü şekli belirtilmiştir. Hatta bilgi veya belgenin belirtilenlerden farklı bir şekilde elde edilmesinin mümkün olması halinde "belgeye zarar vermemek koşuluyla bu olanak sağlanır" ifadesiyle, erişim önündeki engeller kaldırılmak istenmiştir (Bilgi, 2003b). Kamu kurum ve kuruluşları başvuru sahibine istenen belgenin onayIı bir örneğini verirler. Eğer başvuru sahibine verilecek belgenin niteliği kopyasının verilmesine olanaklı değilse veya kopyasını çıkarılmasının aslına zarar vereceği durumlarda, kurum ve kuruluşlar başvuru sahibinin yazılı ve basılı belgeler için, söz konusu belgenin asılını incelemesi ve not almasını, ses kaydı şeklindeki bilgi veya belgeleri dinleyebilmesini, görüntü kaydı şeklindeki bilgi veya belgeleri de izleyebilmesini sağlarlar. Kanunda bilgi edinme başvurusu yapan kişiden, bilgi erişimine olanak sağlandığı bilgi ve belgeler için maliyet tutarı kadar ücret de talep edilebilecektir.

Kanunun 11. maddesinde bilgi ve/veya belgeye erişim süreleri açıklanmıştır. Erişim süreleri Avrupa Birliği'nin konuyla ilgili mevzuatına paralel olarak 15 ila 30 iş günü olarak belirlenmiştir. Asıl olan bilgi veya belgeye erişimi 15 iş günü içinde sağlamaktır. Ancak, maddede belirtilen şartların varlığı halinde erişim 30 iş günü içinde sağlanabilecek, fakat sürenin uzatılması ve bunun gerekçesi başvuru sahibine 15 iş günlük sürenin bitiminden önce yazılı olarak bildirilecektir (Bilgi, 2003a, s. 4). Kurum ve kuruluşlar bilgi edinme başvurularını yazılı olarak ya da elektronik ortamda ilgililere bildirebilirler.

Kanun'da yer alan önemli bir konu da, başvuru sahiplerine hangi bilgilerin verilip verilmeyeceği ve bilgi edinme ile ilgili yapılacak itirazları değerlendirmek ve karar vermek üzere bir "Bilgi Edinme Değerlendirme Kurulu”nun oluşturulmasıdır. Bu Kurul bilgi edinme başvurusuyla ilgili olarak ve istenen bilgi veya belgelerin Devlet sırrı veya Devletin ekonomik menfaatlerine ilişkin olması sebeplerine dayanılarak verilen ret kararlarını itiraz üzerine incelemek ve kurum ve kuruluşlar için bilgi edinme hakkının kullanılmasına ilişkin olarak kararlar vermek üzere kurulmuştur. Kurul, çoğu hukukçu dokuz kişiden meydana gelmektedir (Bilgi, 2003a, s. 4).

Kanun'da da belirtildiği gibi herkes bilgi edinme hakkına sahiptir ancak, bazı istisnai durumlar bilgi edinme hakkı için göz önünde bulundurulması 
gerekmektedir. Dünya üzerindeki genel kabule ve konuyla ilgili yasalara bakıldığında sınırlamalar belli başı bazı alanlarda yapılmaktadır:

- Savunma,

- Uluslararası ilişkiler,

- Ulusal ekonomik çıkarlar,

- Yasaların uygulanması ve adalet sisteminin yönetilmesi,

- Kişi güvenliği,

- Kamusal ve ticari çıkarlar.

Devletin resmi bilgi ve belgelerine erişimde iki tür sınırlama ile karşılaşılmaktadır. Bunlar genelde içerik ve fiziksel sınırlamalardır (Çelik ve Tonta, 1996, ss. 4-5). Kanunda yapılan sınırlamalar da bu doğrultuda gerçekleştirilmiştir. Bu kanun kapsamı dışında kalan durumlar aşağıdaki gibi sıralanabilir:

- Yargı denetimi dışında olan işlemler,

- Devlet sırrına ilişkin bilgi veya belgeler,

- Ülkenin ekonomik çıkarlarına ilişkin bilgi veya belgeler,

- İstihbarata ilişkin bilgi veya belgeler,

- Idari soruşturmaya ilişkin bilgi veya belgeler,

- Adlî soruşturma ve kovuşturmaya ilişkin bilgi veya belgeler,

- Özel hayatın gizliliği,

- Haberleşmenin gizliliği,

- Fikir ve sanat eserleri (Bilgi, 2003a, ss. 5-7).

Kamu kurum ve kuruluşları tarafından bilgi edinme başvurularının değerlendirilmesi ve kanunun işlerliğinin kontrolü açısından kurum ve kuruluşlara bir önceki yıla ait raporlarını hazırlamaları hükmü getirilmiştir. Kurum ve kuruluşlar, aşağıda sıralanan konularla ilgili olarak rapor hazırlamakla yükümlüdürler:

- Kendilerine yapılan bilgi edinme başvurularının sayısını,

- Olumlu cevaplanarak bilgi ve belgelere erişim sağlanan başvuru sayısını,

- Reddedilen başvuru sayısı ve bunların dağılımını gösterir istatistiksel bilgileri,

- Gizli ya da sır niteliğindeki bilgiler çıkarılarak ya da bu nitelikteki bilgiler ayrılarak bilgi veya belgelere erişim sağlanan başvuru sayısını,

- Başvurunun reddedilmesi üzerine itiraz edilen başvuru sayısı ile bunların sonuçlarını; 
gösterir bir rapor hazırlayarak, bu raporları her yıl şubat ayının sonuna kadar Bilgi Edinme Değerlendirme Kurulu'na gönderirler. Bağlı, ilgili ve ilişkili kamu kurum ve kuruluşları raporlarını bağlı, ilgili ya da ilişkili oldukları bakanlık aracılığıyla ileteceklerdir. Bilgi Edinme Değerlendirme Kurulu, kurum ve kuruluşlardan gelen raporların değerlendirilmesiyle hazırlayacağı genel raporu söz konusu kurum ve kuruluşların raporları ile birlikte her yıl nisan ayının sonuna kadar Türkiye Büyük Millet Meclisi Başkanlığınca kamuoyuna açıklanır (Bilgi, 2003a, s. 8).

"Bilgi Edinme Hakkı Kanunu"na hazırlanmakta olan ve üzerinde tartışmaların yapıldığı "Kamu Yönetimi Temel Kanunu Tasarı”nda da atıfta bulunulmaktadır. Tasarının "Kamu Yönetiminde Denetim” başlıkı üçüncü bölümünde: "Gerçek ve tüzel kişiler, kanunla belirlenen usul ve esaslar çerçevesinde bilgi edinme hakkına sahiptir. Kamu kurum ve kuruluşları, gerçek ve tüzel kişilerin talep etmeleri halinde, istenen bilgi ve belgeleri kanunda belirtilen istisnalar dışında vermekle yükümlüdürler. Kamu kurum ve kuruluşları, görev ve hizmet alanlarına giren konulardaki temel nitelikli karar ve işlemlerini, mal ve hizmet alımlarını, satımlarını, projelerini ve yılık faaliyet raporlarını bilgi iletişim teknolojilerini de kullanmak suretiyle kamuoyunun bilgisine sunarlar. Kesinleşen faaliyet ve denetim raporları uygun vasıtalarla kamuoyunun incelemesine açık hale getirilir. Mahalli idarelerde bu raporlar meclislerinin ilk toplantısında üyelerin bilgisine sunulur" şeklinde bu kanunla ilgili temel amaçlar ve sorumluluklar açıklanmıştır (Kamu, 2003, ss. 44-45).

\section{Kurumsal Bilgi Yönetimi Açısından Bilgi Edinme Hakkı Kanunu}

"Bilgi Edinme Hakkı Kanunu"; kamu kurum ve kuruluşlarına, kendi bünyelerinde ürettikleri bilgi ve belgeleri başvuru sahiplerinin -kanun kapsamında yer alan- istekleri doğrultusunda ele alarak değerlendirme işlemlerini düzenlemek amacıyla oluşturulmuştur. Kanunun geneline bakıldığında kamu kurum ve kuruluşlarına sahip oldukları bilgi veya belgeleri denetleme, düzenleme, saklama ve kullanıma açma yükümlülükleri verilmiştir. Bu yükümlülükler, uzun zamandır kamu kurum ve kuruluşlarının bünyesinde olması gereken kurumsal bilgi ve belge yönetimi konularını gündeme getirmiştir. Kurumsal bilgi yönetimi, kurumun kendi bünyesinde doğal faaliyetleri sonucunda ürettiği ve kurum faaliyetlerinin daha verimli ve etkin bir duruma getirilmesi için 
kurum dışından elde ettiği bilginin bir sistem içerisinde denetlenmesinin gerçekleştirmesi açısından önemli bir konudur. Bilgi yönetimi ise; bu çalışmanın kapsamı doğrultusunda, doğru zamanda doğru insanlar için doğru bilgileri elde etme, dağıtma ve organizasyonun gelişmesi için bilgiyi uygun bir format içinde saklama stratejisi olarak ifade edilebilir (Kalseth ve Cummings, 2001, s. 167; Odabaş, 2003, s. 360; Alavi ve Leidner, 2001; ss. 113-114; Özdemirci, 2001, s. 182). Bilgi Edinme Hakkı Kanunu bu bağlamda ele alındığında kamu kurum ve kuruluşlarına getirmiş olduğu yükümlülükler ile, kurumlar ellerindeki bilgiyi ve kanunda tanımlanan tüm belgeleri yönetmek ve kullanıma açmak (paylaşmak) durumundadırlar.

Kurum ve kuruluşların bünyesinde yer alan ve kurumun işlemleri, araştırmaları, projeleri, planları, mal/hizmet üretimleri sürecinde ortaya çıkan belgeler, bu belgelerin depolandığı mekanlar ve bu mekanlarda çalışan kişiler kurumsal bilgi yönetiminin parçalarını meydana getirmektedir. Bilgi Edinme Hakkı Kanununun gerekliliklerini yerine getirmenin yanında kurumsal bilgi yönetimi, kurum ve kuruluşların yönetiminde büyük önem taşır ve bir yönetimin etkinliği de genellikle o kurum veya kuruluşun belgelerinin ne kadar etkin şekilde yönetildiği ile belirlenir.

Kamu kurum ve kuruluşlarının üretmiş oldukları bilgiyi yönetmeleri, bilgi talebinde bulunan kişi veya kurumlara yeterli, doğru ve zamanında bilgi sunma kolaylığı sağlayacaktır. Ancak burada üzerinde önemle durulması gereken bir nokta vardır. Üretilen bilgi ve belgeleri kurum içerisinde kim ya da hangi bölüm, hangi yöntem ve tekniklerle sınıflandıracak, denetleyecek, saklayacak ve kullanıma açacaktır?

Hemen her kurum bünyesinde ürettiği belge ve bilgiyi depoladığı bir bilgi merkezine (arşiv, kütüphane, dokümantasyon merkezi vb.) sahiptir. Hatta bazı kurumlarda kurumun farklı bölümlerinin farklı bilgi ve belge depolama birimleri de bulunmaktadır. Ancak kurum içerisinde yer alan bu merkez ya da birimler bakanlıkların kurulmasına, teşkilat, görev ve yetkilerine ilişkin esas ve usulleri düzenleyen "Bakanlıkların Kuruluş ve Görev Esasları Hakkında Kanun" uyarınca teşkilat içerisinde birer birim olarak gösterilmemektedir (Bakanlıkların, 1984). Bu durum, kurum ve kuruluşlardaki bilgi üretimi, depolanması, sınıflanması ve kullanıma açılması işlemlerinin gerçek anlamıyla yerine getirilmesi ve bu işlemleri yerine getirecek nitelikte personelin bu birim- 
lerde istihdam edilmesini büyük ölçüde engellemektedir. Kurum ve kuruluşlarda sözü edilen işlemlerin hem kurumun verimliliği ve etkinliği hem de "Bilgi Edinme Hakkı Kanunu”nun yükümlülüklerini yerine getirme açısından ele anılıp değerlendirilmesi gerekmektedir. Çünkü kanun kapsamında bilgi edinme başvurusunda bulunacak olan gerçek ve tüzel kişilerin bilgi isteklerinin büyük bir kısmı bu birimlerde depolanan kaynaklardan karşılanacaktır.

Kurumsal bilginin depolandığı birimlerin oluşturulmasının yanı sıra, yapılan bilgi edinme başvurularını karşılamak amacıyla kurum içerisinde üretilen bilgi ve belgeyi sınıflandırabilecek, bibliyografik denetimini yapabilecek, kurumsal bilgi yönetim sürecini işler hale getirecek ve bilgi edinme başvurularına cevap verebilecek yeterliliğe sahip personelin de bu birimlerde görevlendirilmesi gerekmektedir. Sözü edilen işlemleri gerçekleştirecek olan personel, kanun kapsamı dışında bırakılan kamu kurum ve kuruluşlarının kamuya duyurduğu ve yayımladığı bilgi ve belgeleri belirleme ve bunların bibliyografik denetimini sağlama, kurumun üretmiş olduğu belgeleri sınıflama görevlerini yerine getirecektir. Kamu kurum ve kuruluşlarında istihdam edilen ya da edilecek olan bilgi yöneticilerinin görevleri arasında üretilen bilgiyi depolamak, erişmek, yaymak, alıkoymak ve korumak yer almaktadır (Özdemirci, 2001, s. 183). Kurumların arşiv, kütüphane, enformasyon merkezi gibi bölüm ya da birimlerinde istihdam edilecek personelin bilginin sınıflanması, kataloglanması, depolanması, erişimi ve ayıklanması konularında eğitim almış kişilerden oluşması, kurumun hem kendi bilgi yönetimini gerçekleştirmesi hem de kanunun getirdiği bilgi edinme başvurularına cevap verilmesi konularında daha verimli ve olumlu hareket etmesini sağlayacaktır. Bu nedenle kurum ve kuruluşların bünyelerindeki bu birimlere teşkilat yapısı içerisinde yer verilmesi, sözü edilen birimlerde istihdam edilecek olan personelin de bu yapı içerisinde yer alması gerekmektedir.

Kurum ve kuruluşlarda kurumsal bilgi yönetimi, belge yönetimi, bilgi merkezleri ve bu merkezlerde istihdam edilecek personel konularının "Bilgi Edinme Hakkı Kanunu"nun işlerliği açısından sağlayacağı bir diğer fayda daha önce belirtilen ve kanun kapsamı dışında bırakılan bilgi ve belge erişimindeki sınırlamalardır. Kanunda belirtilen sınırlamalar içerisinde yer alan bilgi ve belgelerin tespit edilmesi, içerik ve/veya fiziksel açıdan erişilebilirliğinin belirlenmesi ve kamuya açılacak bilgi ve belgelerden ayrılması; işlemleri sözü 
edilen bilgi ve belgelerin bibliyografik denetiminin yapılması, sınıflandırılması ve depolanması ile mümkün olacaktır.

Kurum ve kuruluşların günlük faaliyetleri sonucunda oluşturulmuş olan belgeler, kurum ve kuruluşun temel bilgi kaynakları arasında yer almaktadır. Bu nedenle "Bilgi Edinme Hakkı Kanunu" kapsamında olan ve sınırlamalar dışında yer alan tüm belgeler de kurum ve kuruluşa yapılacak olan bilgi edinme başvurularına konu olacaktır. Kamu kurum ve kuruluşları 3473 sayılı "Muhafazasına Lüzum Kalmayan Evrak ve Malzemenin Yok Edilmesi Hakkında Kanun Hükmünde Kararnamenin Değiştirilerek Kabulü Hakkında Kanun"nun 3. maddesi ile ellerinde bulunan arşiv malzemelerini her türlü zararlı etkiden ve unsurlardan korumak, asli düzenlerine göre tasnif edip saklamak, yönetmelikte belirlenecek bekletme ve saklama süreleri sonunda Devlet Arşivleri Genel Müdürlüğü'ne teslim etmek ve muhafazasına lüzum kalmayan evrak ve malzemeyi yok etmekle yükümlü kılınmışlardır. Bu kanunun kapsamında mahalli idareler, üniversiteler ve bunlara bağlı sabit ve döner sermayeli kuruluşlar, kamu iktisadi teşebbüsleri, özel kanunlarla kurulan kamu bankaları ve teşekkülleri girmektedir (Muhafazasına, 1988; Gürsoy, Kuş, Şen ve Akdemir, 1996, ss. 29-31).

3473 sayılı kanun, kamu kurum ve kuruluşlarına getirdiği bu yükümlülük, üretilen belgelerin sınıflanmasına, belirli bir süre korunarak saklanmasına ve gerektiğinde kullanıma açılmasına yönelik işlemleri göstermektedir. Bu işlemler kurum ve kuruluşların ürettikleri ve dışarıdan elde ettikleri bilgi ve belgeleri, bilgi edinme başvurusu yapanların isteklerini karşılamak için kullanmalarında ve bilgi verme yükümlülüklerini yerine getirmelerinde belirleyici bir rol oynamaktadır. Lüzumu kalmayan evrakın ve diğer malzemenin ayıklanması ve imhası aynı zamanda kurum ve kuruluşların ellerindeki bilgi ve belgenin bibliyografik yönden denetlemesini de beraberinde getirmektedir. Bu ayrım ve imha işıemi, "Bilgi Edinme Hakkı Kanunu”nun kapsam dışı bıraktığı alanların ve bu alanlarla ilgili bilgi ve belgelerin de belirlenmesine yardımcı olacaktır. Bu noktadan hareketle "Bilgi Edinme Hakkı Kanunu" kapsamında tanımlanan bilgi ve belge kavramlarına, bunların sınıflanmasına, saklanmasına ve kullanılmasına 3473 sayılı kanun ile dolaylı olarak değinilmiş ve bazı yükümlülükler getirilmiştir. Bu kanunla kamu kurum ve kuruluşlarını bünyelerinde bulunan arşiv, kütüphane vb. bölümler daha işlevsel olarak kullanılacak, olmayan 
kurumlar ise bu bölümleri oluşturma çabası içerisine girecektir. "Bilgi Edinme Hakkı Kanunu" her ne kadar 3473 sayılı kanunu atıf olarak göstermese de dolaylı olarak bu kanunun amaç ve kapsamının oluşturulmasına, tanımlamalarının yapılmasına ve işlemesine yardımcı olmuştur.

"Bilgi Edinme Hakkı Kanunu”, sadece gerçek kişilerin değil, diğer özel ve kamu kurumlarının da bilgi edinme haklarının olduğunu vurgulamaktadır. Kurumlar kendi aralarında ancak sınırlamalar göz önüne alınarak bilgi ve belge talebinde bulunabilirler. Kamu kurum ve kuruluşları arasında bilgi alıp verme ile ilgili göze çarpan ilk düzenlemelerden biri olan ve 1951 yılında yürürlüğe giren "Mali İstihbarat Arşivi Yönetmeliği"dir. Bu yönetmeliğin bilgi isteme ve bilgi verme başlığını taşıyan ikinci bölümü; vergi dairelerinin ellerinde bulundurması gereken ve gerektiğinde ilgili kurumlara göndermesi istenilen bilgi ve belgelerin niteliğini ve sürekli olarak bilgi vermesi gereken kurumları açıklamaktadır (Mali, 1951). 1989 yılında sözü edilen yönetmelik temel alınarak yeni bir düzenlemeye gidilmiş ve "Tapu Sicil Müdürlükleri lçin Tapu Siciline Kayıtı Gayrimenkullerle IIIgili Olarak Açıklanan Esaslar Çerçevesinde Sürekli Bilgi Verme Zorunluluğu Getirilmesi ile İlgili Tebliğ” hazırlanmış ve yürürlüğe girmiştir. Yapılan bu düzenlemelerle kamu kurum ve kuruluşları arasındaki bilgi alıp verme işlemleri düzene girmiş, ilgili kurumların ellerindeki bilgiyi yükümlülükleri çerçevesinde saklayıp kullanıma açmaları sağlanmıştır (Vergi, 1989). Bu karşılıklı istek, kurumların kendi üretmiş oldukları bilgiyi yönetmeleri gerektiğinin bir diğer kanıtını oluşturmaktadır. Burada önemli olan nokta kurumsal bilgi yönetiminin temelini oluşturan belge yönetiminin gerçekleştirilmesidir.

Kamu kurum ve kuruluşlarındaki belge yönetiminin temel amacı, kurumun faaliyetleri sonucu üretilen tüm belgeleri, üretim aşamasından itibaren ele alarak belirlenmiş ölçütler çerçevesinde değerlendirmek, düzenlemek ve istenildiğinde hizmete sunmak için sürekli olarak kullanıma hazır bulundurmaktır (Özdemirci, 2001, s. 182). Bilgi yönetimi; üretilen belgelerin karar verme aracı olma, kurumsal verimliliği sağlama, yasa koyucu ve düzenleyicilerin bilgi gereksinimlerini karşılama ve yeni belge ve bilgiler üretmek gibi fonksiyonları vardır (Özdemirci, 1996, s. 15). Belge yönetimin sahip olduğu bu özellikler ve fonksiyonlar, "Bilgi Edinme Hakkı Kanunu”nun amacını gerçekleştirirken stratejik bir noktada yer almasını sağlamaktadır. 
Kurumlararası bilgi paylaşımı ile ilgili girişimler e-Türkiye çalışmalarında da bulunmaktadır. Kurumlararası bilgi paylaşımı e-Avrupa çalışmaları kapsamında ele alınmış ve sağlayacağı yararlar şu şekilde belirtilmiştir:

- Kurumlararası -özellikle de aynı yapı ve statüye sahip kurumlar içinbilgi birliği sağlanır ve bilgi ve belge tekrarı engellenir.

- Zaman, iş gücü ve mali kayıplar engellenir.

- Hızlı ve doğru karar alma ortamı sağlanır.

- Bilgiye kolay, hızlı ve güvenli erişim sağlanır.

- Üretilen bilgi ve belgelerin kaybolması önlenir (Arifoğlu, Körnes, YazıCl, Akgül ve Ayvalı, 2002, s. 106).

"Bilgi Edinme Hakkı Kanunu"nun 6. maddesinde bilgi edinme başvurularının nasıl yapılması gerektiği ve bilgi edinme başvurusu sahibinin dilekçede yer alması gereken bilgileri belirtilmiştir. Ayrıca başvuru sahibinin kimliğinin ve imzasının veya yazının kimden neşet ettiğinin tespitine yarayacak başka bilgilerin yasal olarak belirlenebilir olması kaydıyla başvurunun elektronik ortamda veya diğer iletişim araçlarıyla da yapılabilirliği belirtilmiştir. Burada başvurulara yazılı cevabın yanı sıra elektronik ve diğer iletişim yollarıyla da cevap verilebileceği ön plana çıkartılmaktadır. Başvuruların elektronik olarak karşılanması elektronik postaların, ekli dosyaların, başvuru formlarının da sınıflanmasını, değerlendirilmesini, cevaplanmasını ve saklanmasını zorunlu kılacaktır. Bir başka deyişle yazılı olarak bilgi edinme taleplerinin karşılanması için gereken işlemler elektronik ortamdaki talepler için de uygulanacaktır.

Elektronik ortamda bilgi edinme taleplerinin yapılabilmesi için öncelikle gerçekleştirilmesi gereken işlem belirli bir formatta hazırlanması gereken bilgi edinme talep dilekçeleridir. Bu dilekçede kanunun 6. maddesindeki bilgileri içerecek alanlar tanımlanmalı ve istenilen bir dosya biçiminde ilgili kurumların web sayfalarına konulmalıdır. Elektronik ortamda bilgi edinme başvurusu yapmayı kolaylaştırıcı düzenleme 23.01.2004 tarihli ve 25355 sayılı Resmi Gazete'de yayınlanan “Elektronik Imza Kanunu”dur. Bu kanun, "Bilgi Edinme Hakkı Kanunu”nun 6. maddesinde elektronik ortamda bilgi edinme başvurusu dilekçesinde yer alması gereken başvuru sahibi imzasının hukuksal ve teknik yönlerini açıklamaktadır. "Elektronik Imza Kanunu”, elektronik imzanın hukuki yapısını, elektronik sertifika hizmet sağlayıcılarının faaliyetlerini ve her alanda elektronik imzanın kullanımına ilişkin işlemleri kapsamaktadır 
(Elektronik, 2004, ss. 1-3). Elektronik imzanın bilgi edinme başvurularında da kullanılmaya başlaması en azından başvuru sürecini kısaltmak açısından kolaylıklar sağlayacaktır.

"Bilgi Edinme Hakkı Kanunu"nun kamu kurum ve kuruluşlarına getirmiş olduğu yükümlülüklerden biri, bilgi edinme başvurularının durumlarını belirten düzenli raporların kurum ve kuruluşlar tarafından hazırlanmasıdır. Rapor hazırlama yükümlülüğü, Kanun'un ne şekilde ve ne kadar uygulandığı konusunda üst kurumlara bilgi verecektir.

Bilgi edinme ve bilme hakkı, demokratik bir sistemi benimsemiş her siyasi yapının temel amacı olan hesap verme ile yakından bağlantılıdır. Ayrıca, hükümetlerin açıklık kültürü temelinde, işlemlerini yurttaşlarına açması, saydam ve katılımcı bir demokrasi anlayışının gelişmesi için oldukça önemlidir. Saydam ve katılımcı bir demokrasinin gelişimi için iyi ve dürüst yönetim anlayışının da gelişmesi gereklidir.

Kamu kurum ve kuruluşlarında üretilen bilgilerin dağıtımı ve bu bilgilere erişim konusu da bilgi edinme özgürlüğü ile ilgilidir. Vatandaşlar kendi ödedikleri vergiler kullanılarak üretilen bilgilere erişim hakkına sahiptirler.

\section{Sonuç}

"Bilgi Edinme Hakkı Kanunu" vatandaşların kamu kurum ve kuruluşlarından bilgi talep etme isteklerinin genel hükümlerini belirlemektedir. Kamu kurum ve kuruluşları kendi özellikleri, yönetmelikleri, hizmet şekillerini temel alarak iç düzenlemelerini bu kanun çerçevesinde hazırlayacaklardır. Bilgi Edinme Hakkı Kanunu kamu kurum ve kuruluşlarının ellerinde bulundurdukları bilgi ve belgeleri daha etkin bir biçimde yönetmelerini, hizmete açmalarını, belge üretimlerini standartlaştıracak, kurumlararası bilgi alış-verişini geliştirecek, gereksiz bilgi ve belge üretimini azaltacak, vatandaşların kamu kurum ve kuruluşlarının faaliyetleri ile daha ayrıntılı bilgi edinme olanağı sağlayacaktır. Kurum ve kuruluşların üretmiş oldukları kurumsal bilgi bu sayede kontrol altına alınacak güvenlik, gizlilik ve paylaşılabilirlik sınırları belirlenecektir. Kanunda belirtilen bilgi edinme başvurularının ve bu başvuruların cevaplanmasının elektronik ortamda da yapılabilmesi, kamu kurum ve kuruluşlarını elektronik ortamda üretmiş oldukları belgeleri de kontrol edip standartlaştırmasını beraberinde getirecektir. 
Bu kanunun çıkarılması, daha önce belirtildiği gibi, e-Türkiye Projesi Kısa Dönem Eylem Planı (2003-2004) Bilgi Toplumu Stratejisi içerisinde yer almış ve 2003 senesi içerisinde çıkarılması planlanmıştır. Bu kanunu daha verimli bir biçimde ve amaçlanan çerçeve içerisinde sağlıklı yürütülebilmesi için yine sözü edilen proje ve e-Türkiye Girişimi Eylem Planı içerisinde çıkarılması tasarlanan "Kişisel Verilerin Korunması Hakkında Kanun", "Ulusal Bilgi Güvenliği Kanunu" ve "Bilgi Toplumu Tanıtım ve Enformasyon Bakanlığı" kurma çalışmaları ile beraber ele alındığında çok daha etkin bir uygulama alanı oluşabilecektir.

Bilgi edinme hakkındaki yasanın, uygulamada pek çok zorluğa, karmaşaya, anlaşmazlığa yol açacağı söylenebilir. Gerçi, yurttaşların bu yasayı kullanmadaki ilgisinin ya da hukukçuların ve medyanın bunu duyurmadaki heyecanının/isteğinin ne olacağı tam olarak kestirilemeyebilir.

"Bilgi Edinme Hakkı Kanunu" çerçevesinde kamu kurum ve kuruluşları bünyesinde oluşturulması gerekecek ya da hali hazırda var olan arşiv, kütüphane, enformasyon merkezi, dokümantasyon merkezi, bilgi yönetim birimleri ve benzerinde daha önce bahsedilen özelliklerde meslekten kişilerin istihdam edilmesi ile birlikte kurumsal bilgi yönetimi, bilgi-belge yönetimi faaliyetleri ve bilgi edinme hakkı kanununun yükümlülükleri daha sağlıklı ve doğru bir biçimde yerine getirilebilecektir.

Demokrasinin ve hukukun üstünlüğünün gereklerinden olan bilgi edinme hakkı, bireylere daha yakın bir yönetimi, halkın denetimine açıklığı, şeffaflığı sağlama işlevlerinin yanı sıra halkın devlete karşı duyduğu kamu güvenini daha yüksek düzeylere çıkarmada önemli bir rol oynamaktadır. Kullanılan bu hak sayesinde hem halkın devleti denetimi kolaylaşmakta, hem de devletin demokratik karakteri güçlenmektedir.

\section{Kaynakça}

Alavi, M. ve Leidner, D. E. (2001). Knowledge management and knowledge management systems: Conceptual foundations and research issues. MIS Quarterly 25 (1), 107-136.

Arifoğlu, A., Körnes, A., Yazıcı, A., Akgül, M. K. ve Ayvalı, A. (Derl.). (2002). E-devlet yolunda Türkiye. Ankara: Türkiye Bilişim Derneği. 
Bakanlıkların Kuruluş ve Görev Esasları Hakkında 174 Sayılı KHK ile 13/12/1983 Gün ve 174 Sayılı Bakanlıkların Kuruluş ve Görev Esasları Hakkında KHK'nin Bazı Maddelerinin Değiştirilmesi Hakkında 202 Sayılı KHK'nin Değiştirilerek Kabulü Hakkında Kanun. (1984, 9 Ekim). T.C. Resmi Gazete, 18540. 23 Aralık 2003 tarihinde http://proje.basbakanlik.gov.tr/mevzuat/mevzuat.asp adresinden erişildi. Bilgi Edinme Hakkı Kanunu. (2003a, 24 Ekim). T.C. Resmi Gazete, 25269. Bilgi Edinme Hakkı Kanunu Tasarısı. (2003b). 23 Aralık 2003 tarihinde http://www.adalet.gov.tr/kanun/Tasari/bilgiedinme.htm adresinden erişildi.

Çelik, A. ve Tonta, Y. (1996). Düşünce özgürlüğü, bilgi edinme özgürlüğü ve bilgi hizmetleri. A. Çelik ve Y. Tonta (Yay. Haz.), Bilgi Edinme Özgürlüğü içinde (ss. 1-13). Ankara: Türk Kütüphaneciler Derneği.

Elektronik Imza Kanunu. (2004, 23 Ocak). T.C. Resmi Gazete, 25355.

Freedom of Information (FOI) Laws. (2004). 11 Mart 2003 tarihinde http://home.online.no/ wkeim/foil.htm\#english adresinden erişildi.

Genelge 2003/48. (2003). T.C. Resmi Gazete, 25306.

Gürsoy, Ş., Kuş, M., Şen, S. ve Akdemir, E. S. (Yay. Haz.). (1996). Başbakanlık Devlet Arşivleri Genel Müdürlügü Cumhuriyet Arşivi Daire Başkanlığı rehberi (2. bsk.). Ankara: T.C. Başbakanlık Devlet Arşivleri.

İimsoy, A. O. (1996). Idari belgelere erişim hakkı: Bilgi edinme özgürlüğü kanunları. A. Çelik ve Y. Tonta (Yay. Haz.), Bilgi Edinme Özgürlüğü içinde (ss. 46-54). Ankara: Türk Kütüphaneciler Derneği.

Idari Usul ve Bilgi Edinme Hakkı Kanunu (Ön Taslak). (1999). 20 Aralık 2003 tarihinde http://www.basbakanlik.gov.tr/genelgevekanunlar/ idariusul/idariusul.html adresinden erişildi.

Kalseth, K. ve Cummings, S. (2001). Knowledge management:

Development strategy or business strategy? Information Development, 17 (3), 163-172.

Kamu Yönetimi Temel Kanunu Tasarısı: Kamu yönetiminde yeniden yapılanma-2. (2003). Ankara: T.C. Başbakanlık.

Mali İstihbarat Arşivi Yönetmeliği. (1951, 21 Temmuz). T.C. Resmi Gazete, 7864. 11 Ocak 2004 tarihinde http://proje.basbakanlik.gov.tr/mevzuat/ mevzuat.asp adresinden erişildi. 
Muhafazasına Lüzum Kalmayan Evrak ve Malzemenin Yok Edilmesi Hakkında Kanun Hükmünde Kararnamenin Değiştirilerek Kabulü Hakkında Kanun. (1988, 4 Mart). T.C. Resmi Gazete, 19949. 11 Ocak 2004 tarihinde http://proje.basbakanlik.gov.tr/mevzuat/mevzuat.asp adresinden erişildi.

Odabaş, H. (2003). Kurumsal bilgi yönetimi. Türk Kütüphaneciliği, 17 (4), 357-368.

Özdemirci, F. (1996). Kurum ve kuruluşlarda belge üretiminin denetlenmesi ve belge yönetimi. İstanbul: Türk Kütüphaneciler Derneği.

Özdemirci, F. (2001). Belge üretimi ve kurumsal bilgi yönetimi. T. Fenerci ve O. Gürdal (Yay. Haz.), 21. Yüzyıla Girerken Enformasyon Olgusu Uluslararası Sempozyum Bildirileri: 19-20 Nisan 2001 içinde (ss. 179189). Ankara: Türk Kütüphaneciler Derneği.

T.C. Anayasası. (1999). Ankara: Yetkin Yayınları.

Tortop, N. (2003). Bilgi edinme hakkı kanunu tasarısı üzerine. 19 Aralık 2003 tarihinde http://www.izmirbarosu.org.tr/mevzuat/inceleme _bilgi_edinme_hakki_yasa_tasarisi.htm\#_ftnref2 adresinden erişildi.

Vergi Usul Kanunu Genel Tebliğ: Sıra No: 193. (1989, 10 Mayıs). T.C. Resmi Gazete, 20161. 